\title{
Effects of gastric sleeve surgery on the serum levels of GH, IGF-1 and IGF-binding protein 2 in healthy obese patients
}

\author{
Khalid Al-Regaiey ${ }^{1}$, Suad Alshubrami ${ }^{1,2}$, Ibrahim Al-Beeshi ${ }^{1}$, Torki Alnasser ${ }^{1}$, Abdulnasser Alwabel', \\ Hassan Al-Beladi ${ }^{1}$, Omar Al-Tujjar ${ }^{1}$, Abdulrahman Alnasser ${ }^{1}$, Assim A. Alfadda ${ }^{3,4}$ and Muhammad lqbal ${ }^{1 *}$
}

\begin{abstract}
Background: Bariatric surgery is an effective treatment for severe obesity. It also ameliorates diabetes independently of weight loss through mechanisms that are not fully understood. In this study, we investigated the levels of GH, IGF-1 and IGF-binding protein 2 (IGFBP-2) after gastric sleeve surgery in healthy obese individuals.

Method: This study was conducted in 33 obese (BMI > 38.3) healthy male subjects aged 25 to 50 years undergoing sleeve gastrectomy. GH, IGF-1 and IGFBP-2 levels were evaluated by ELISA at baseline and 6-12 months after surgery. Other parameters, such as glucose, BMI, insulin, HOMA-IR and lipid profile, were also investigated.

Results: Systemic GH (12.32 vs. $50.97 \mathrm{pg} / \mathrm{mL}, p<0.001)$ and IGFBP-2 levels (51.86 vs. $68.81 \mathrm{pg} / \mathrm{mL}, p<0.001)$ were elevated after bariatric surgery. There was no change in IGF-1 level from before to after surgery. BMI (52.18 vs. 40.11, $p=0.001$ ), insulin (19.35 vs. $8.80 \mathrm{mIU} / \mathrm{L}, p<0.001)$ and HOMA-IR index (6.48 to $2.52, p<0.001$ ) were reduced after surgery. Lipid profile analysis revealed that total cholesterol $(4.26$ vs. $5.12 \mathrm{mmol} / \mathrm{L}, p<0.001)$ and high-density lipoprotein (HDL) $(0.90$ to $1.55 \mathrm{mmol} / \mathrm{L}, p<0.001)$ were increased, while triglycerides were decreased, after surgery (1.62 vs. $1.05 \mathrm{mmol} / \mathrm{L} p<0.001$ ). GH, IGF-1, and IGFBP-2 were not correlated with insulin or lipid parameters.

Conclusions: Our study suggests that improved circulating GH and IGFBP-2 levels may mediate the beneficial effects of gastric sleeve surgery in improving insulin sensitivity and reducing insulin demand.
\end{abstract}

Keywords: Gastric sleeve surgery, Growth hormone, IGF-1, IGFBP-2, Obesity

\section{Background}

Obesity remains a continuing global health concern, and its prevalence has doubled since 1980. According to WHO estimates, in 2016, more than 650 million people are obese, and 1.9 billion people are overweight [1]. It is associated with an increased risk of many chronic diseases, including type 2 diabetes (T2D), hypertension, and cardiovascular disease (CVD). Obesity can be defined simply as abnormal or excessive body fat

\footnotetext{
* Correspondence: saadhafsa@hotmail.com

'Department of Physiology, College of Medicine, King Saud University, Riyadh, Saudi Arabia

Full list of author information is available at the end of the article
}

accumulation to such an extent that health may be adversely affected.

Growth hormone $(\mathrm{GH})$ and insulin-like growth factor 1 (IGF-1) have major roles in metabolic regulation, reproduction and ageing. GH is produced by the anterior pituitary gland in response to growth hormone-releasing hormone $(\mathrm{GHRH})$, which is released by the hypothalamus as a normal reflection of multiple features, such as hypoglycaemia, low free fatty acids in the blood, high amino acids, good exercise and sleep [2]. All these features are diminished in adult subjects with high BMI [3]. Following an increase in BMI, GH secretion is reduced, and lipid metabolism is disturbed, leading to

(c) The Author(s). 2020 Open Access This article is licensed under a Creative Commons Attribution 4.0 International License, which permits use, sharing, adaptation, distribution and reproduction in any medium or format, as long as you give appropriate credit to the original author(s) and the source, provide a link to the Creative Commons licence, and indicate if changes were made. The images or other third party material in this article are included in the article's Creative Commons licence, unless indicated otherwise in a credit line to the material. If material is not included in the article's Creative Commons licence and your intended use is not permitted by statutory regulation or exceeds the permitted use, you will need to obtain permission directly from the copyright holder. To view a copy of this licence, visit http://creativecommons.org/licenses/by/4.0/. The Creative Commons Public Domain Dedication waiver (http://creativecommons.org/publicdomain/zero/1.0/) applies to the data made available in this article, unless otherwise stated in a credit line to the data. 
increased T2D and cardiovascular disease risk [4]. IGF-1 reflects $\mathrm{GH}$ levels and mediates its growth effects, while the metabolic effects of $\mathrm{GH}$, including stimulation of lipolysis and inhibition of insulin signalling in fat and muscle, are induced directly through the $\mathrm{GH}$ receptor [5]. IGF-1 in the circulation binds to IGF-binding proteins (IGFBPs). These IGFBPs act as transporter proteins, modulate IGF-1 actions and regulate its clearance [6]. In obesity, non-esterified fatty acids and insulin inhibit IGFBP production, which increases free IGF-1 in circulation [7].

IGFBP-2 is one of the most abundant IGFBPs and is responsible for several cellular processes, such as cell proliferation, migration, and adhesion, which play a significant role in cancer establishment and progression $[8,9]$. It is secreted by differentiating preadipocytes. Plasma IGFBP-2 level can be used as a biomarker of insulin sensitivity, as it helps in glucose metabolism by improving insulin sensitivity [10]. Increased IGFBP-2 has had a strong negative association with the risk of T2D and BMI $[11,12]$. Lower circulating levels of IGFBP-2 have been linked with an increased risk of developing metabolic syndrome and increased levels of triglyceride-rich particles [13].

Bariatric surgery is an effective treatment for severe obesity that leads to the improvement and remission of many obesity-related comorbidities, sustained weight loss over time, improvement in quality of life and prolonged survival $[14,15]$. Bariatric surgery reduces body weight and improves glycaemic control through reduced nutrient intake and malabsorption. However, other mechanisms, such as changes in the secretion and activity of hormones and neurotransmitters involved in appetite, energy expenditure and glucose metabolism, also add to the beneficial effects of bariatric surgery $[16,17]$.

The underlying mechanisms of how bariatric surgery influences the physiological metabolic process pre- and post-surgery are not fully understood. Therefore, the aim of this study was to assess the activity of the $\mathrm{GH} /$ IGF-1 axis and IGFBP-2 levels in obese patients before and 6-12 months after gastric sleeve surgery and their correlations with other anthropometric parameters and lipid profile.

\section{Methods}

\section{Subjects}

This study was conducted in the Departments of Physiology and Surgery, College of Medicine and Obesity Research Centre, King Khalid University Hospital, King Saud University. This study included 33 healthy male subjects aged 25 to 50 years with obesity grades II \& III who qualified for laparoscopic sleeve gastrectomy, were not taking medications, did not have severe postoperative complications, and had complete data at the 12-month postoperative follow-up. Informed written consent was signed by all the participants. This study was approved by the Institutional Review Board, College of Medicine, King Saud University, Riyadh, Saudi Arabia (E-17-2652).

\section{Clinical examinations and blood collection}

All patients were clinically examined by a physician, a psychologist and a nutritionist before surgery and attended surgery and nutrition clinics at 3, 6 and 12 months after surgery. The patients were not on medication for kidney, thyroid, or liver disorders and were taking oral vitamins. BMI was recorded at each visit, and patients were classified according to their BMI results. Blood was taken from patients in the fasting state one day before surgery and 6-12 months later. Serum was separated following centrifugation at $1500 \times$ g for $10 \mathrm{~min}$ and stored at $-80^{\circ} \mathrm{C}$ in aliquots within $30 \mathrm{~min}$ of collection. Other parameters, such as routine $\mathrm{CBC}$, lipid profile, glucose, insulin, and liver function test results, were retrieved from the hospital files.

\section{Enzyme-linked Immunosorbent assay (ELISA)}

GH, IGF-1 and IGFBP-2 levels were analysed by indirect Simple Step Human ELISA kits (GH Ab190811, IGF-1 Ab100545 and IGFBP-2 Ab100540) following the manufacturer's instructions (abcam, Cambridge, UK). Briefly, patient samples (33 pre- and 33 post-bariatric surgery) and standards were reacted with specific antibodies coated in the microplates for each protein under investigation and incubated at room temperature $\left(18-25^{\circ} \mathrm{C}\right)$ for $1 \mathrm{~h}$ on a plate shaker. Next, the cocktail of antibodies (capture and detector antibodies) was added and incubated as before. One hundred microliters of TMB substrate was added to the microplate and incubated as previously described. The reactions were stopped by adding $100 \mu \mathrm{l}$ stop solution to each well, and the absorbance was read by a microplate reader (EL 800, BioTek Instruments, USA) at $450 \mathrm{~nm}$.

\section{Statistical analysis}

Data were analysed using SPSS (IBM Corp. Released 2012. IBM SPSS Statistics for Windows, Version 21.0. Armonk, NY: IBM Corp.). Categorical data are expressed as absolute numbers and percentages. Numerical data are expressed as mean, median, standard error of the mean (SEM) and range. Student's t-test was used to compare the data pre- and post-surgery. A p value < 0.05 was considered statistically significant.

\section{Results}

Anthropometric and biochemical assessments

Anthropometric data of the 33 obese male patients are shown in Table 1. BMI decreased after bariatric surgery (52.18 \pm 9.86 vs. $40.11 \pm 8.92 \mathrm{~kg} / \mathrm{m}^{2}$ [mean $\pm \mathrm{SEM}$ ] $6-12$ months after surgery, $p<0.001$ ). 
Table 1 Anthropometric baseline characteristics of the study subjects

\begin{tabular}{lll}
\hline Variable & Mean & SEM \\
\hline Age (years) & 35.12 & 0.249 \\
Height $(\mathrm{cm})$ & 170.97 & 0.005 \\
Weight $(\mathrm{kg})$ & 150.16 & 0.77 \\
\hline
\end{tabular}

Total cholesterol (TC) and high-density lipoprotein (HDL) levels were increased post-bariatric surgery (4.26 \pm 0.027 vs. $5.12 \pm 0.026 \mathrm{mmol} / \mathrm{L}$ and $0.90 \pm 0.007$ vs. $1.55 \pm$ $0.011 \mathrm{mmol} / \mathrm{L}, p<0.001$, respectively). There was also a significant increase in low-density lipoprotein (LDL) level post-bariatric surgery ( $2.62 \pm 0.026$ vs. $2.98 \pm 0.022 \mathrm{mmol} /$ $\mathrm{L}, p<0.031$ ). Triglycerides (TGL) were decreased after bariatric surgery $(1.62 \pm 0.038$ vs. $1.05 \pm 0.012 \mathrm{mmol} / \mathrm{L}$, $p=0.028$, Table 2). Insulin level was decreased from $19.35 \pm 0.304$ to $8.80 \pm 0.181 \mathrm{mIU} / \mathrm{L}, p<0.001$, and the Homeostatic Model Assessment-Insulin resistance (HOMA-IR) index was reduced from $6.48+0.164$ to $2.52 \pm 0.061, p<0.001$, Table 2). There was no significant difference in glucose level before vs. after surgery.

\section{Analysis of GH, IGF-1 and IGFBP-2 levels in serum before and after surgery}

Analysis of the serum level of $\mathrm{GH}$ showed an increase post-bariatric surgery $(12.32 \pm 1.3$ vs. $50.97 \pm 0.339 \mathrm{pg} /$ $\mathrm{mL}, p<0.001$ ), while IGF-1 level did not exhibit a significant change before vs. after surgery $(4414.38 \pm 58.81$ vs. $3730.74 \pm 43.649 \mathrm{ng} / \mathrm{mL}$, Fig. 1 -a and Fig. 1-b). IGFPB-2 increased after surgery (from $51.86 \pm 0.34$ to $68.81 \pm 0.405 \mathrm{pg} / \mathrm{mL}, p<0.001$, Fig. $1-\mathrm{c})$. There was no correlation between GH, IGF-1, or IGFBP-2 and BMI, insulin or lipid parameters (data not shown).

\section{Discussion}

Bariatric surgical procedures are effective options for longterm obesity treatment to obtain sustained weight loss and substantial improvement of comorbidities and quality of life. Reduced stomach volume and malabsorption are not

Table 2 Demographic and clinical measurements before and after surgery

\begin{tabular}{llll}
\hline Parameters & $\begin{array}{l}\text { Pre-Surgery } \\
\text { Mean } \pm \text { SEM }\end{array}$ & $\begin{array}{l}\text { Post-Surgery } \\
\text { Mean } \pm \text { SEM }\end{array}$ & $p$ value \\
\hline BMI $\left(\mathrm{kg} / \mathrm{m}^{2}\right)$ & $52.18 \pm 0.299$ & $40.11 \pm 0.270$ & 0.001 \\
GLUC $(\mathrm{mmol} / \mathrm{L})$ & $7.08 \pm 0.085$ & $6.27 \pm 0.031$ & 0.681 \\
TGL $(\mathrm{mmol} / \mathrm{L})$ & $1.62 \pm 0.038$ & $1.05 \pm 0.012$ & 0.028 \\
TC $(\mathrm{mmol} / \mathrm{L})$ & $4.26 \pm 0.027$ & $5.12 \pm 0.026$ & $<0.001$ \\
HDL $(\mathrm{mmol} / \mathrm{L})$ & $0.90 \pm 0.007$ & $1.55 \pm 0.011$ & $<0.001$ \\
LDL $(\mathrm{mmol} / \mathrm{L})$ & $2.62 \pm 0.026$ & $2.98 \pm 0.022$ & 0.031 \\
HOMA-IR index & $6.48 \pm 0.164$ & $2.52 \pm 0.061$ & $<0.001$ \\
Insulin $(\mathrm{mlU} / \mathrm{L})$ & $19.35 \pm 0.304$ & $8.80 \pm 0.181$ & $<0.001$ \\
\hline
\end{tabular}

the only means by which bariatric surgery improves insulin action and associated parameters; alterations in endocrine response are thought to play important roles in the beneficial effects [18]. The aim of this study was to evaluate the effects of gastric sleeve surgery on glycaemic control, lipid profile, GH, IGF-1 and IGFBP-2 among the Saudi adult male population. $\mathrm{GH}$ and IGFBP-2 levels were increased after bariatric surgery, while IGF-1 level was not altered. Insulin sensitivity was increased, as reflected by a decrease in insulin level and HOMA-IR index.

The somatotropic axis has an important role in maintaining healthy conditions, and it is suppressed in obesity due to reduced GH and IGF-1 levels in the body. Hyperinsulinaemia and high circulating free fatty acids reduce IGFBP-1 production by the liver, which is responsible for reduced $\mathrm{GH}$ production from the pituitary and consequently low IGF-1 levels [19].

IGF-1 has an important role in GH activity and is related to its serum levels. Increased IGF-1 levels in obesity have a negative effect and cause GH suppression [20,21]. In the current study, $\mathrm{GH}$ was elevated after gastric sleeve surgery, while IGF-1 was not changed. Insulin can bind to the IGF-1 receptor, and IGF-1 can bind to the insulin receptor, and both stimulate growth and hypoglycaemic effects. Moreover, hybrid heterodimeric receptors can be formed consisting of an insulin and an IGF-1 receptor $\alpha-\beta$ dimer, which signal mainly IGF-1 [22]. After bariatric surgery, GH was increased, but IGF-1 was not. It is possible that IGF-1 signalling is enhanced since HOMA-IR was improved. High, low and normal levels of IGF-1 have been reported in obese populations $[19,20]$. Our results are in agreement with previous studies reporting no change in IGF levels postoperatively [23, 24]. However, an earlier decrease ( 3 weeks to 1 month) and an increase 1 year after bariatric surgery have also been reported $[25,26]$. In obese children, reduced $\mathrm{GH}$ is not associated with decreased levels of IGF-1 or reduced somatic growth [21]. In our study, cholesterol, HDL and LDL were increased after bariatric surgery, but they were still within the desired physiological levels. An increase in the lipid profile can be explained by the lipolytic effects of $\mathrm{GH}$ and the release of free fatty acids from visceral adipose tissue and, to a lesser extent, from subcutaneous fat by increasing hormonesensitive lipase (HSL). Furthermore, GH maintains triglyceride storage in the liver by either inhibiting triglyceride lipolysis via HSL or oxidation by PPAR $\gamma$ [27]. GH also stimulates triglyceride uptake into skeletal muscle to be used for energy or stored as intramyocellular lipids [28]. Furthermore, as a result of bariatric surgery, calorie intake is reduced, which might lead to increased GH levels since its secretion is stimulated by hypoglycaemia. Increased $\mathrm{GH}$ after bariatric surgery has beneficial effects on maintaining proper glucose levels and preventing liver steatosis. In the liver, $\mathrm{GH}$ stimulates autophagy and preserves 


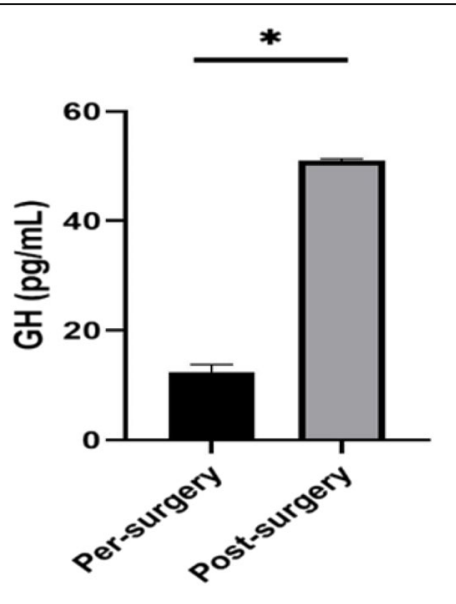

a

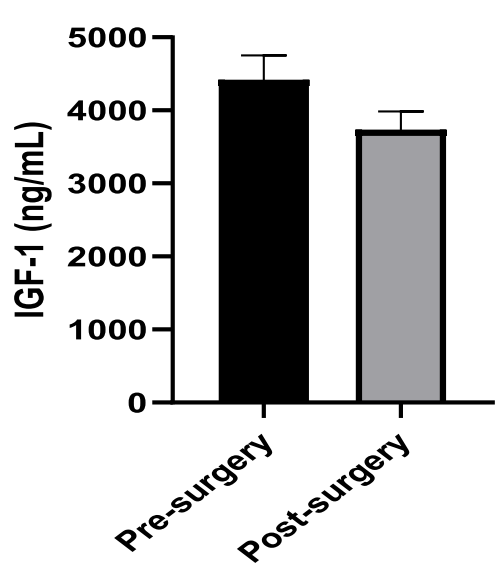

b

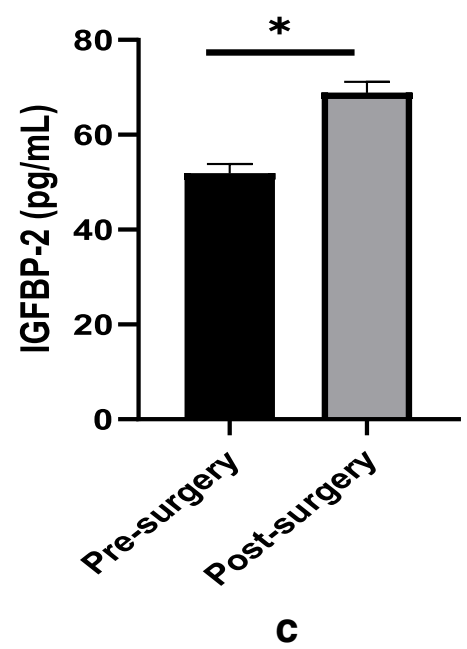

Fig. 1 a-c. Serum levels of GH, IGF-1 and IGFBP-2 in patients before and after bariatric surgery $(p<0.001)$

plasma glucose levels in chronically starved mice [29]. Moreover, GH signalling in the liver is essential to regulate intrahepatic lipid metabolism, while IGF-1 helps in reducing the catabolic effects of $\mathrm{GH}$ [30]. In the current study, although the elevated levels of TC, LDL and HDL may be in part due to increased GH level, there are several potential reasons for this, and not just attributable to increased GH levels.

IGFBP-2 is the main IGF-binding protein associated with regulating body weight and homeostasis and protects against obesity and insulin resistance [10, 31-33]. Obesity-related hyperinsulinaemia increases IGF-1 and inhibits IGFBP-2 secretion [34]. In our study, IGFBP-2 was increased, while insulin level, HOMA-IR index and BMI were reduced 6-12 months after gastric sleeve surgery. IGFBP-2 concentration has been associated with improvements in insulin sensitivity, BMI and lipid profile in obesity-related studies. A recent 20-year longitudinal study of ageing has shown that IGFBP-2 level increases with age, positively correlates with insulin sensitivity, and negatively correlates with BMI at baseline and follow-up [34]. In obese children, circulating levels of IGFBP-2 correlate negatively with body mass and positively with insulin sensitivity [35]. A recent animal study has shown that metformin upregulates IGFBP-2 production through activation of the AMPK-Sirt1PPAR $\alpha$ signalling pathway [36]. Metformin-treated diabetic patients have higher IGFBP-2 levels and lower serum IGF1 levels than untreated patients [36]. This highlights IGFBP-2 as a novel target for metformin action and AMPK-Sirt1-PPAR $\alpha$ as a novel pathway to control metabolic syndrome. IGFBP-2 was shown to be increased after biliopancreatic diversion in obese patients and was associated with improved glucose and lipid levels that were sustained even after one year of followup [37]. IGFBP-2 has also been shown to be regulated by leptin and may mediate some of leptin's antidiabetic effects [38]. Early increased levels of IGFBP-2 were 
noticed after gastric bypass but normalized shortly after [38]. It was recently reported that higher basal levels of IGFBP-2 were associated with lower risk of metabolic syndrome and type 2 diabetes and its levels increased after bariatric surgery [39]. In the current study, the role of IGFBP-2 is suggested to potentially mediate some of the beneficial effects of the sleeve gastrectomy in a healthy male population.

Our study subjects were a small number of homogenous males without medical complications. Future studies should be conducted in a larger sample including women and control lean subjects undergoing non-bariatric laparoscopic surgery for comparison.

\section{Conclusions}

In conclusion, our study suggests that GH and IGFBP-2 levels may be an endocrine response that may in part mediate the beneficial effects of sleeve gastrectomy by improving insulin sensitivity and reducing insulin demand.

\section{Acknowledgements}

We would like to thank the Obesity Research Centre and all participants of this study. We also acknowledge and appreciate the help of the medical team and laboratory technicians.

\section{Authors' contributions}

$\mathrm{KA}$ and $\mathrm{Ml}$ conceived the idea, designed the proposal, performed the experiment, analysed the data, and wrote and edited the manuscript. $\mathrm{AA}^{3}$ (Assim A Alfadda) conceived the idea, designed the proposal, provided the samples and contributed to the final concept and design. SA, IA, TA, AA ${ }^{1}$ (Abdulnasser Alwabel), HA, OA, and $A^{2}{ }^{2}$ (Abdulrahman Alnasser) performed data collection, statistical analysis, write-up of results, and formatting and editing of the manuscript. All authors approved and read the manuscript in its current state.

\section{Funding}

This work was supported by the College of Medicine Research Centre, Deanship of Scientific Research, King Saud University, Riyadh, Saudi Arabia. The funding body played no role in the design of the study and collection, analysis, and interpretation of data and in writing the manuscript.

\section{Availability of data and materials}

The data used and analysed during the current study are available from the corresponding author on reasonable request.

\section{Ethics approval and consent to participate}

This study was approved by the Institutional Review Board, Ethics Committee, College of Medicine Research Centre (E-17-2652). Informed written consent was obtained from all the participants.

\section{Consent for publication}

Not applicable.

\section{Competing interests}

The authors declare that they have no competing interests.

\section{Author details}

${ }^{1}$ Department of Physiology, College of Medicine, King Saud University, Riyadh, Saudi Arabia. ${ }^{2}$ Current Address: Director of Academic and Training Affairs Continuous Professional, King Salman Specialist Hospital, Hail, Saudi Arabia. ${ }^{3}$ Obesity Research Center, College of Medicine, King Saud University, Riyadh, Saudi Arabia. ${ }^{4}$ Department of Medicine, College of Medicine, King Saud University, Riyadh, Saudi Arabia.
Received: 16 December 2019 Accepted: 19 May 2020

Published online: 25 June 2020

\section{References}

1. Blüher M. Obesity: global epidemiology and pathogenesis. Nat Rev Endocrinol. 2019;15:288-98.

2. Møller N, Jørgensen JO. Effects of growth hormone on glucose, lipid, and protein metabolism in human subjects. Endocr Rev. 2009;30(2):152-77.

3. Lichanska AM, Waters MJ. How growth hormone controls growth, obesity and sexual dimorphism. Trends Genet. 2008;24:41-7.

4. Rasmussen MH. Obesity, growth hormone and weight loss. Mol Cell Endocrinol. 2010;316:147-53.

5. Lewitt MS. The role of the growth hormone/insulin-like growth factor system in visceral adiposity. Biochem Insights. 2017;10:1-10.

6. Firth SM, Baxter RC. Cellular actions of the insulin-like growth factor binding proteins. Endocr Rev. 2002;23:824-54

7. Mittempergher F, Pata G, Crea N, Di Betta E, Vilardi A, Chiesa D, Nascimbeni R. Preoperative prediction of growth hormone $(\mathrm{GH})$ /insulin-like growth factor-1 (IGF-1) axis modification and postoperative changes in candidates for bariatric surgery. Obes Surg. 2013:23:594-601.

8. Hedbacker K, Birsoy K, Wysocki RW, Asilmaz E, Ahima RS, Farooqi IS, Friedman JM. Antidiabetic effects of IGFBP2, a leptin-regulated gene. Cell Metab. 2010;11:11-22.

9. Probst-Hensch NM, Steiner JH, Schraml P, Varga Z, Zürrer-Härdi U, Storz M, Korol D, Fehr MK, Fink D, Pestalozzi BC, Lütolf UM, Theurillat JP, Moch H. IGFBP2 and IGFBP3 protein expressions in human breast cancer: association with hormonal factors and obesity. Clin Cancer Res. 2010;16:1025-32.

10. Ko JM, Park HK, Yang S, Kim EY, Chung SC, Hwang IT. Association between insulin-like growth factor binding protein-2 levels and cardiovascular risk factors in Korean children. Endocr J. 2012;59:335-43.

11. Rajpathak SN, He M, Sun Q, Kaplan RC, Muzumdar R, Rohan TE, Gunter MJ, Pollak M, Kim M, Pessin JE, Beasley J, Wylie-Rosett J, Hu FB, Strickler HD. Insulin-like growth factor axis and risk of type 2 diabetes in women. Diabetes. 2012;61:2248-54

12. Ahmed RL, Thomas W, Schmitz KH. Interactions between insulin, body fat, and insulinlike growth factor axis proteins. Cancer Epidemiol Biomark Prev. 2007;16:593-7.

13. Carter S, Li Z, Lemieux I, et al. Circulating IGFBP-2 levels are incrementally linked to correlates of the metabolic syndrome and independently associated with VLDL triglycerides. Atherosclerosis. 2014;237(2):645-51.

14. Mingrone G, Panunzi S, De Gaetano A, Guidone C, laconelli A, Nanni G, Castagneto M, Bornstein S, Rubino F. Bariatric-metabolic surgery versus conventional medical treatment in obese patients with type 2 diabetes: 5 year follow-up of an open-label, single-Centre, randomised controlled trial. Lancet. 2015:386:964-73.

15. Adams TD, Gress RE, Smith SC, Halverson RC, Simper SC, Rosamond WD, Lamonte MJ, Stroup AM, Hunt SC. Long-term mortality after gastric bypass surgery. N Engl J Med. 2007;357:753-61.

16. Holst JJ, Madsbad S, Bojsen-Møller KN, Svane MS, Jørgensen NB, Dirksen C, Martinussen C. Mechanisms in bariatric surgery: gut hormones, diabetes resolution, and weight loss. Surg Obes Relat Dis. 2018;14:708-14.

17. Dimitriadis GK, Randeva MS, Miras AD. Potential hormone mechanisms of bariatric surgery. Curr Obes Rep. 2017;6:253-65.

18. Kizy S, Jahansouz C, Wirth K, Ikramuddin S, Leslie D. Bariatric surgery: a perspective for primary care. Diabetes Spectr. 2017;30:265-76.

19. Maccario M, Grottoli S, Procopio M, Oleandri SE, Rossetto R, Gauna C, Arvat E, Ghigo E. The GH/IGF-I axis in obesity: influence of neuro-endocrine and metabolic factors. Int J Obes Relat Metab Disord. 2000:24:596-9.

20. Frystyk J. Free insulin-like growth factors-measurements and relationships to growth hormone secretion and glucose homeostasis. Growth Horm and IGF Res. 2004;14:337-75.

21. Kreitschmann-Andermahr I, Suarez $P$, Jennings $R$, Evers N, Brabant G. GH/ IGF-I regulation in obesity--mechanisms and practical consequences in children and adults. Horm Res Paediatr. 2010;73:153-60.

22. Yakar S, Adamo ML. Insulin-like growth factor 1 physiology: lessons from mouse models. Endocrinol Metab Clin N Am. 2012:41(2):231-47.

23. Brynskov T, Laugesen SC, Floyd AK, Frystyk J, Sørensen TL. The IGF-Axis and diabetic retinopathy before and after gastric bypass surgery. Obes Surg. 2017:27:408-15

24. Vilarrasa N, Gómez JM, Elio I, et al. Evaluation of bone disease in morbidly obese women after gastric bypass and risk factors implicated in bone loss. Obes Surg. 2009;19:860-6. 
25. Pardina E, Ferrer R, Baena-Fustegueras JA, et al. The relationships between IGF-1 and CRP, NO, leptin, and adiponectin during weight loss in the morbidly obese. Obes Surg. 2010;20:623-32.

26. Itariu BK, Zeyda M, Prager G, et al. Insulin-like growth factor 1 predicts postload hypoglycemia following bariatric surgery: a prospective cohort study. PLoS One. 2014;9:e94613-9.

27. Bogazzi F, Ultimieri F, Raggi F, Russo D, Vanacore R, Guida C, Viacava P, Cecchetti D, Acerbi G, Brogioni S, Cosci C, Gasperi M, Bartalena L, Martino E. PPARgamma inhibits GH synthesis and secretion and increases apoptosis of pituitary GH-secreting adenomas. Eur J Endocrinol. 2004;150:863-75.

28. Vijayakumar A, Novosyadlyy R, Wu Y, Yakar S, LeRoith D. Biological effects of growth hormone on carbohydrate and lipid metabolism. Growth Hormon IGF Res. 2010;20(1):1-7.

29. Fang F, Shi X, Brown MS, Goldstein JL, Liang G. Growth hormone acts on liver to stimulate autophagy, support glucose production, and preserve blood glucose in chronically starved mice. Proc Natl Acad Sci U S A. 2019; 116(15):7449-54.

30. Fan Y, Menon RK, Cohen P, Hwang D, Clemens T, DiGirolamo DJ, Kopchick $J$ J, Le Roith D, Trucco M, Sperling MA. Liver-specific deletion of the growth hormone receptor reveals essential role of growth hormone signaling in hepatic lipid metabolism. J Bio Chem. 2009;284(30):19937-44.

31. Assefa B, Mahmoud AM, Pfeiffer AFH, Birkenfeld AL, Spranger J, Arafat AM. Insulin-like growth factor (IGF) binding Protein-2, independently of IGF-1, induces GLUT-4 translocation and glucose uptake in 3T3-L1 adipocytes. Oxidative Med Cell Longev. 2017;2017:3035184.

32. Xi G, Solum MA, Wai C, Maile LA, Rosen CJ, Clemmons DR. The heparinbinding domains of IGFBP-2 mediate its inhibitory effect on preadipocyte differentiation and fat development in male mice. Endocrinology. 2013;154: 4146-57.

33. Wheatcroft SB, Kearney MT, Shah AM, Ezzat VA, Miell JR, Modo M, Williams SC, Cawthorn WP, Medina-Gomez G, Vidal-Puig A, Sethi JK, Crossey PA. IGFbinding protein-2 protects against the development of obesity and insulin resistance. Diabetes. 2007;56:285-294.

34. van den Beld AW, Carlson OD, Doyle ME, Rizopoulos D, Ferrucci L, van der Lely AJ, Egan JM. IGFBP-2 and aging: a 20-year longitudinal study on IGFBP2, IGF-I, BMI, insulin sensitivity and mortality in an aging population. Eur J Endocrinol. 2019;180:109-16.

35. Yau SW, Harcourt BE, Kao KT, Alexander EJ, Russo VC, Werther GA, Sabin MA. Serum IGFBP-2 levels are associated with reduced insulin sensitivity in obese children. Clin Obes. 2018;8:184-90.

36. Kang HS, Cho HC, Lee JH, Oh GT, Koo SH, Park BH, Lee IK, Choi HS, Song DK, Im SS. Metformin stimulates IGFBP-2 gene expression through PPARalpha in diabetic states. Sci Rep. 2016;6:23665.

37. Li Z, Martin J, Poirier P, Caron-Cantin SM, Hould FS, Marceau S, Marceau P, Picard F. Upregulation of plasma insulin-like growth factor binding protein 2 levels after Biliopancreatic diversion in humans. Obesity. 2012;20(7):146973.

38. Ceccarini G, Pelosini C, Ferrari F, Magno S, Vitti J, Salvetti G, Moretto C Marioni A, Piero Buccianti P, Piaggi P, Maffei M, Santini F. Serum IGF-binding protein 2 (IGFBP-2) concentrations change early after gastric bypass bariatric surgery revealing a possible marker of leptin sensitivity in obese subjects. Endocrine. 2019;65:86-93.

39. Shah RV, Hwang SJ, Yeri A, Tanriverdi K, Pico AR, Yao C, Murthy V, Ho J, Vitseva O, Demarco D, Shah S, lafrati MD, Levy D, Freedman JE. Proteins altered by surgical weight loss highlight biomarkers of insulin resistance in the community. Arteriosclerosis Thromb Vasc Biol. 2019;39(1):107-15.

\section{Publisher's Note}

Springer Nature remains neutral with regard to jurisdictional claims in published maps and institutional affiliations.

Ready to submit your research? Choose BMC and benefit from:

- fast, convenient online submission

- thorough peer review by experienced researchers in your field

- rapid publication on acceptance

- support for research data, including large and complex data types

- gold Open Access which fosters wider collaboration and increased citations

- maximum visibility for your research: over $100 \mathrm{M}$ website views per year

At BMC, research is always in progress.

Learn more biomedcentral.com/submissions 